\title{
Phosphorus nutrition of plants: a microbial perspective
}

\begin{abstract}
Challenges in agriculture are increasing day by day. Sustainable nutrition of plants is one of the major concerns now a day. It is a major challenge to provide sufficient nutrient like phosphorus to the plants. Nutrition of phosphorus is of major concern as it is poorly available and having essential role for growth and development of plants. Fixation of applied phosphorus makes the situation worst. In this situation, few of the microorganisms efficiently dissolve fixed phosphorus forms so that it can be taken up by plants. Varieties of mechanisms are involved in phosphorus solubilization. Different microbes have been reported in almost all the agricultural crops for phosphorus solubilization. These microbes are not only providing precious phosphorus to the plants but also reduce the input cost by saving some parts of phosphatic fertilizers. In this review, different plant microbial interactions involved in phosphorus nutrition is discussed.
\end{abstract}

Volume 2 Issue 6 - 2017

\author{
Amrita Gupta,' Pramod Kumar Sahu² \\ 'Department of Biotechnology, MS Ramaiah College of Arts, \\ Science and Commerce, India \\ ${ }^{2}$ National Bureau of Agriculturally Important Microorganisms, \\ India
}

Correspondence: Pramod Kumar Sahu, National Bureau of Agriculturally Important Microorganisms, Kushmaur, Mau, UP, India-275103, Email pramod15589@gmail.com

Received: August 01, 2017| Published: October 03, 2017

Keywords: phosphorus nutrition, p-fixation, phosphorus solubilization, plant-microbe interaction

\section{Microbial agents in plant nutrition}

Expanding world population demands more food and other produce to sustain and support life. Present agriculture production majorly depends on heavy agrochemical inputs. Nutrients are necessary for plant growth and this have to be replenish in soil. Unfortunately, the practice is to supply only nitrogen, phosphorus and potassium to it. Apart from fertilizers, a huge amount of chemical is poured for pest control and growth promotion in plants. These heavy chemical inputs also have negative impacts on soil fertility. ${ }^{1}$ Microorganisms are sustainable partial substitutes for costly and hazardous agrochemicals. Microbes provide benefits to plants by enhancing nutrition, protecting from abiotic stresses and biotic stresses. Phosphorus (P) is one of very crucial fertilizer for plants and most important next to Nitrogen in limiting plant productivity. In last 50years, phosphorus use has increased by four times. ${ }^{2}$ Plants need $\mathrm{P}$ for carrying out vital functions as it is part of nucleic acids, energy transfer, photosynthesis, respiration, etc. ${ }^{3}$ Although $\mathrm{P}$ is available in large quantities in soil, it is not present in plant-available forms. Substantial amount of the applied phosphorus also tend to get fixed in soil colloids in form of $\mathrm{Ca}, \mathrm{Al}$ and $\mathrm{Fe}$ phosphates. This all left only small amount (below $1 \%$ ) of phosphorus directly available to plants. ${ }^{4}$ Large array of microorganisms help plant in this situation by solubilizing fixed $\mathrm{P}$ of soil. Bacillus megaterium. Acinetobacter sp. Penicillium, Glomus, Gigaspora, etc. are prominent microorganisms help plant in efficient P-uptake. These microbes establish interaction with host plants and provide P-nutrition to plants. Arbuscular mycorrhizal (AM) fungi are very popular P-mobilizers found as symbiont in most of the crops. ${ }^{5}$ It enhances the nutrient absorption by roots by enhancing surface beyond the depletion zone. ${ }^{6}$ Apart from P mobilization, Am fungi also help plant in absorption of nitrogen, potassium, calcium, sulfur, and micronutrients like $\mathrm{Fe}, \mathrm{Zn}$ and $\mathrm{Cu} .{ }^{7,8}$ Some of the bacterial genera are associated with beneficial effects of mycorrhiza, called as mycorrhiza helping bacteria ${ }^{5}$ or mycorrhizospheric. ${ }^{9}$ They support mycorrhiza and plants by producing plant growth promoting effects, nitrogen fixation, P-solubilization, phytohormones, siderophores and antimicrobials, etc. ${ }^{5}$ There are countless such interactions in and around plant roots that enhances ultimate uptake of phosphorus by plants. A significant correlation found between numbers of P-solubilizers and the levels of total $\mathrm{P}$ in soil. ${ }^{10}$

\section{Mechanisms of Phosphorus Solubilization}

Several mechanisms have been determined which are responsible for solubilization of fixed phosphorus. Most common mechanism for solubilization of mineral phosphate is production of organic acid like citric acid, succinic acid, lactic acid, propionic acid, gluconic acid and keto gluconic acids. ${ }^{11-13}$ Organic and inorganic acids produced by phosphorus solubilizing microbes, chelate cations bound to phosphate by their hydroxyl and carboxyl groups and thus release phosphorus in soluble forms. Production of phosphatase enzyme is another mechanism. Acid phosphatases play a significant role in organic phosphorus mineralization in soil. Microbes from genera like Pseudomonas, Bacillus, Acinetobacter, Rhizobium, Alcaligenes, Arthrobacter, Azospirillum, Burkholderia, Enterobacter, Erwinia, Flavobacterium, Paenibacillus, Serratia, Penicillium, Trichoderma and Aspergillus are the most powerful P-solubilizing bacteria and fungi. ${ }^{13}$ Siderophore production also releases phosphorus by chelating Fe (Table 1).

\section{Mobilization of phosphorus}

Fungus like arbuscular mycorrhizal fungi (AMF) facilitates mobilization of easily available-forms from place away from reach of plant roots and thus enhances availability of phosphorus to plants. Mycorrhiza makes symbiotic relationship with plant roots and other bacteria which enhance phosphorus solubilization and ultimately lead to good plant growth. ${ }^{14}$ Mycorrhiza benefits from plant by getting carbon from it and in turn provides water, phosphorus, $\mathrm{Zn}$, calcium, copper, etc. which would not be accessible to host. Mycorrhiza facilitates the host roots in nutrient absorption by its fine absorbing hyphae. Popular mycorrhizal genera are Glomus, Gigaspora, Acaulospora, Scutellospora, Archaeospora, Entrophospora and Paraglomus, which probably they make most abundant fungal genera in crop lands as it account for almost $5-50 \%$ of the total soil microbial biomass ${ }^{15} \mathrm{In}$ per $\mathrm{cm}$ plant roots approximately 10 to $100 \mathrm{~m}$ mycorrhizal mycelium can be present and produce glomalin which 
improves soil health. ${ }^{16} \mathrm{AM}$ fungi also help plants in water absorption in dry seasons by improving hydraulic conductivity of plant roots. ${ }^{17} \mathrm{It}$ also induce defense in plants, lignifications and protect against plant pathogens by competing for space and colonization. ${ }^{18-23} \mathrm{AM}$ fungi improve P-nutrition of plants in different P-levels of soil. ${ }^{24-26}$

Table I Some of the prominent effects of P-solubilizers in plants

\begin{tabular}{|c|c|c|c|c|}
\hline S. no & P-Solubilizer & Crop & Effect & Reference \\
\hline I & $\begin{array}{l}\text { B. circulans and B. megaterium } \\
\text { var. phosphaticum }\end{array}$ & Pea & Increase P-uptake and plant biomass & Raj et al. ${ }^{26}$ \\
\hline 2 & B. subtilis & Mung bean & Increase $\mathrm{P}$ and $\mathrm{N}$-uptake, biomass and grain yield, & Gaind \& Gaur ${ }^{21}$ \\
\hline 3 & $\begin{array}{l}\text { AM fungi and Aspergillus niger } \\
\text { BCC F. } 194\end{array}$ & $\begin{array}{l}\text { Solubilization in liquid } \\
\text { culture }\end{array}$ & Bioactivation of rock $-\mathrm{P}$ & Goenadi et al. ${ }^{22}$ \\
\hline 4 & G. mosseae and P. thomii & Mentha piperita & Increased plant growth and rock-P solubilization & Cabello et al. ${ }^{20}$ \\
\hline 5 & PSB & $\begin{array}{l}\text { Different food and forage } \\
\text { crops }\end{array}$ & Improve biological nitrogen fixation, $\mathrm{P}$ solubilization & $\begin{array}{l}\text { Ponmurugan \& } \\
\text { Gopi }^{25}\end{array}$ \\
\hline 6 & PSB & Aerobic rice & Solubilization of different $P$ forms & Panhwar et al..$^{24}$ \\
\hline 7 & $\begin{array}{l}\text { Acidithiobacillus } \\
\text { ferrooxidans and } \\
\text { Acidithiobacillus thiooxidans }\end{array}$ & $\begin{array}{l}\text { In shake flask leaching } \\
\text { experiment }\end{array}$ & Solubilization of rock-P containing sulfur-mud & Bhatti et al. ${ }^{14}$ \\
\hline 8 & Acinetobacter sp. & Finger millet & Increased $\mathrm{P}$ uptake and plant growth & Sahu et al. $2016 a$ \\
\hline 9 & Pseudomonas Fluorescens & Cotton & Enhance growth and yield & Hassan et al. ${ }^{23}$ \\
\hline 10 & $\begin{array}{l}\text { S. meliloti, Streptomyces sp., } \\
\text { Bacillus sp. }\end{array}$ & Maize & Icrease mycorrhizal colonization, P-uptake, plant growth & Battini et al..$^{25}$ \\
\hline
\end{tabular}

\section{Conclusion}

Phosphorus is very important for plant growth and yield and also prone for fixation in soil. The serious problem of fixation reduces P-use efficiency and enhances cost of production. P-solubilizing microorganisms are boon for this problem and confer many other benefits to plants. Inoculation with efficient P-solubilizing microorganisms can therefore enhance plant productivity and reduce cost of cultivation. Research leads are also necessary for improving efficiency of existing P-solubilizers, finding their new roles in plant growth, exploring novel microbes for P-solubilization, finding novel mechanisms for further higher P-solubilization efficiency, etc.

\section{Acknowledgments}

Authors are grateful to their respective institutes for support and encouragement.

\section{Conflicts of interest}

The authors declare there is no conflict of interests.

\section{Funding}

None.

\section{References}

1. Lal R. Climate strategic soil management. Challenges. 2014;5:43-74.

2. Chen M, Graedel TE. A half-century of global phosphorus flows, stocks, production, consumption, recycling, and environmental impacts. Glob Environ Change. 2016;36:139-152.

3. Schachtman DP, Reid RJ, Ayling SM. Phosphorus uptake by plants:from soil to cell. Plant Physiol. 1998;116(2):447-453.

4. Karandashov V, Bucher M. Symbiotic phosphate transport in arbuscular mycorrhizas. Trends Plant Sci. 2005;10(1):22-29.

5. Battini F, Grønlund M, Agnolucci M, et al. Facilitation of phosphorus uptake in maize plants by mycorrhizosphere bacteria. Sci Rep. 2017;7(1):4686.
6. Philippot L, Raaijmakers JM, Lemanceau P, et al. Going back to the roots:the microbial ecology of the rhizosphere. Nat Rev Microbio. 2013;11(11):789-799.

7. Garci K, Zimmermann SD. The role of mycorrhizal associations in plant potassium nutrition. Front Plant Sci. 2014;5:337.

8. Lehmann A, Rillig MC. Arbuscular mycorrhizal contribution to copper, manganese and iron nutrient concentrations in crops-A meta-analysis. Soil Biol Biochem. 2015;81:147-158.

9. Agnolucci M, Battini F, Cristani C, et al. Diverse bacterial communities are recruited on spores of different arbuscular mycorrhizal fungal isolates. Biol Fert Soils. 2015;51(3):379-389.

10. Kucey RMN. Phosphate-solubilizing bacteria and fungi in various cultivated and virgin Alberta soils. Canadian Journal of Soil Science. 1983;63:671-678.

11. Goldstein AH. Recent progress in understanding the molecular genetics and biochemistry of calcium phosphate solubilization by Gram negative bacteria. Biological agriculture \& Horticulture. 1995;12(2):185-193.

12. Kim KY, Jordan D, Krishnan HB. Rahnella aqualitis, a bacterim isolated from soybean rhizosphere, can solubilize hydroxyapatite. FEMS Microbiology Letter. 1997;153(2):273-277.

13. Sharma S, Kumar V, Tripathi RB. Isolation of phosphate solubilizing microorganism (PSMs) from soil. $J$ Microbiol Biotech Res. 2017;1(2):90-95.

14. Bhatti TM, Yawar W. Bacterial solubilization of phosphorus from phosphate rock containing sulfur-mud. Hydrometallurgy. 2010;103(1):54-59.

15. Olsson PA, Thingstrup I, Jakobsen I, et al. Estimation of the biomass of arbuscular mycorrhizal fungi in a linseed field. Soil Biology and Biochemistry. 1999;3(13):1879-1887.

16. Lovelock CE, Wright SF, Clark DA, et al. Soil stocks of glomalin produce by arbuscular mycorrhizal fungi across a tropical rain forest landscape. Journal of Ecology. 2004;92(2):278-287.

17. Mahdi SS, Hassan GI, Samoon SA, et al. Bio-Fertilizers In Organic Agriculture. Journal of Phytology. 2010;2(10):42-54. 
18. Kasiamdar RS, Smith SE, Smith FA, et al. Influence of the mycorrhizal fungus, Glomus coronatum, and soil phosphorus on infection and disease caused by binucleate Rhizoctonia and Rhizoctonia solani on mung bean (Vigna radiata). Plant and Soil. 2001;238(2):235-244.

19. Ergin SF, Gülser F. Effect of mycorrhiza on growth criteria and phosphorus nutrition of lettuce (Lactuca sativa L.) under different phosphorus application rates. Eurasian Journal of Soil Science (EJSS). 2016;5(4):275-278

20. Cabello M, Irrazabal G, Bucsinszky AM, et al. Effect of an arbuscular mycorrhizal fungus, G. mosseae and a rock-phosphate-solubilizing fungus, P. thomii in Mentha piperita growth in a soil less medium. $J$ Basic Microbiol. 2005;45(3):182-189.

21. Gaind S, Gaur AC. Thermotolerant phosphate solubilizing microorganisms and their interactions in mungbean. Plant Soil. 1991;133(1):141-149.

22. Goenadi DH, Siswanto, Sugiarto Y. Bioactivation of poorly soluble phosphate rocks with a phosphate solubilizing fungus. Soil Science Society of America Journal. 2000;64(3):927-932.

23. Hassan ZU, Geroge S, Rajpar I, et al. ACC-Deaminase, PhosphateSolubilizing Pseudomonas Fluorescens Enhance Cotton Growth and Yield Under Phosphorus Deficiency Stress. Sindh University Research Journal-SURJ (Science Series). 2016;48(4).

24. Panhwar QA, Radziah O, Sariah M, et al. Solubilization of different phosphate forms by phosphate solubilizing bacteria isolated from aerobic rice. Int J Agric Biol. 2009;11(6):667-673.

25. Ponmurugan P, Gopi C. Distribution pattern and screening of phosphate solubilizing bacteria isolated from different food and forage crops. Journal of Agronomy. 2006;5(4):600-604.

26. Raj J, Bagyaraj DJ, Manjunath A. Influence of soil inoculation with vesicular-arbuscular mycorrhiza and a phosphate dissolving bacterium on plant growth and ${ }^{32} \mathrm{P}-$ uptake. Soil Biology and Biochemistry. 1981;13(2):105-108. 